\title{
Percent Mammographic Density and Dense Area as Risk Factors for Breast Cancer
}

\section{Prozentuale mammografische Dichte und die dichte Fläche in der Mammografie als Risikofaktoren für das Mammakarzinom}

Authors

Affiliations
C. Rauh ${ }^{1}$, C. C. Hack ${ }^{1}$, L. Häberle ${ }^{1}$, A. Hein ${ }^{1}$, A. Engel ${ }^{1}$, M. G. Schrauder ${ }^{1}$, P. A. Fasching ${ }^{1}$, S. M. Jud ${ }^{1}$, A. B. Ekici², C. R. Loehberg ${ }^{1}$, M. Meier-Meitinger ${ }^{3}$, S. Ozan ${ }^{1}$, R. Schulz-Wendtland ${ }^{3}$, M. Uder ${ }^{3}$, A. Hartmann ${ }^{4}$, D. L. Wachter ${ }^{4}$, M. W. Beckmann ${ }^{1}$, K. Heusinger ${ }^{1}$

The affiliations are listed at the end of the article

\section{Key words}

- mammographic density

- breast cancer

risk

Schlüsselwörter

- mammografische Dichte

- Mammakarzinom

- Erkrankungsrisiko received 21.6.2012

revised 28.6.2012

accepted 29.6.2012

\section{Bibliography}

DOI http://dx.doi.org/

10.1055/s-0032-1315129

Geburtsh Frauenheilk 2012; 72 :

727-733 @ Georg Thieme

Verlag KG Stuttgart · New York ISSN 0016-5751

\section{Correspondence}

\section{Prof. Dr. Peter A. Fasching}

University Hospital Erlangen

Department of Gynecology and

Obstetrics

91054 Erlangen

peter.fasching@uk-erlangen.de

\section{Abstract}

$\nabla$

Purpose: Mammographic characteristics are known to be correlated to breast cancer risk. Percent mammographic density (PMD), as assessed by computer-assisted methods, is an established risk factor for breast cancer. Along with this assessment the absolute dense area (DA) of the breast is reported as well. Aim of this study was to assess the predictive value of DA concerning breast cancer risk in addition to other risk factors and in addition to PMD.

Methods: We conducted a case control study with hospital-based patients with a diagnosis of invasive breast cancer and healthy women as controls. A total of 561 patients and 376 controls with available mammographic density were included into this study. We describe the differences concerning the common risk factors BMI, parital status, use of hormone replacement therapy (HRT) and menopause between cases and controls and estimate the odds ratios for PMD and DA, adjusted for the mentioned risk factors. Furthermore we compare the prediction models with each other to find out whether the addition of DA improves the model.

Results: Mammographic density and DA were highly correlated with each other. Both variables were as well correlated to the commonly known risk factors with an expected direction and strength, however PMD $(\rho=-0.56)$ was stronger correlated to BMI than DA $(\rho=-0.11)$. The group of women within the highest quartil of PMD had an OR of 2.12 (95\% CI: 1.25-3.62). This could not be seen for the fourth quartile concerning DA. However the assessment of breast cancer risk could be improved by including DA in a prediction model in addition to common risk factors and PMD.

Conclusions: The inclusion of the parameter DA into a prediction model for breast cancer in addition to established risk factors and PMD could im-

\section{Zusammenfassung \\ $\nabla$}

Ziel: Das Erscheinungsbild der Brustdrüse in der Mammografie konnte mit dem Brustkrebsrisiko in Zusammenhang gebracht werden. Die prozentuale mammografische Dichte (PMD) ist ein etablierter Risikofaktor für das Mammakarzinom. Bei der computergestützten Bestimmung der PMD wird gleichzeitig die Fläche der dichten Anteile (DA) berechnet. Ziel dieser Studie ist es festzustellen, ob durch die Hinzunahme der DA die Prädiktion des Brustkrebsrisikos verbessert werden kann.

Methoden: Wir führten eine Fallkontrollstudie durch, die krankenhausbasierte Brustkrebspatientinnen als Fälle und gesunde Individuen als Kontrollen rekrutiert hat. Insgesamt $561 \mathrm{~Pa}-$ tientinnen und 376 Kontrollindividuen mit einer mammografischen Dichte wurden in diese Untersuchung eingeschlossen. Die Unterschiede zwischen Fällen und Kontrollen in Bezug auf allgemeine Brustkrebsrisikofaktoren werden beschrieben und die adjustierten Odds Ratios (OR) für die PMD und die DA in Bezug auf das Brustkrebsrisiko berechnet. Außerdem werden die verschiedenen Prädiktionsmodelle in Bezug auf ihre Stärke, den Fallkontrollstatus vorherzusagen, verglichen.

Ergebnisse: PMD und DA waren hochgradig miteinander korreliert. Beide Variablen waren auch mit den üblichen Risikofaktoren wie dem Alter, dem BMI, der Parität, und der Benutzung von Hormonersatztherapie (HRT) assoziiert. PMD ( $\rho=$ -0.56) war deutlicher mit dem BMI assoziiert als die DA $(\rho=-0.11)$. Die Gruppe von Frauen in der höchsten Quartile der PMD hatten eine OR von 2,12 (95\%-KI: 1,25-3,62) verglichen mit Frauen in der niedrigsten Quartile. Dies konnte nicht für die DA gezeigt werden. Jedoch bei der Bildung eines Prädiktionsmodells für den Fallkontroll- 
prove the breast cancer risk assessment. As DA is measured together with PMD in the process of computer-assisted assessment of PMD it might be considered to include it as one additional breast cancer risk factor that is obtained from breast imaging. status hatte das Modell, welches die Risikofaktoren, die PMD und die DA einschloss, die beste Vorhersagekraft.

Schlussfolgerung: Die Fläche der dichten Anteile der Brust bei einer Mammografie (DA) kann die Bestimmung des Brustkrebsrisikos verbessern, wenn sie zusammen mit üblichen Risikofaktoren und der prozentualen mammografischen Dichte (PMD) benutzt wird. Da die DA bei computergestützten Messungen der mammografischen Dichte ohnehin bestimmt wird, sollte überlegt werden, ob dieser Faktor nicht generell bei der Risikobestimmung integriert werden sollte.

\section{Introduction}

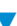

Breast cancer risk prediction has improved a lot over the last decades. Both genetic and nongenetic risk factors have been studied in many case-control and cohort studies [1]. It is thought that about $20-25 \%$ of all familial breast cancer cases can be explained by known genetic susceptibility variants [2]. Familial breast cancer risk remains one of the most important risk factors for breast cancer, with a relative risk (RR) of about 1.8-2.6 in case a first degree relative has been diagnosed with breast cancer [3]. Over the last decade the importance of mammographic density as one of the major risk factors became more and more evident and has been shown to modify the risk for breast cancer with an odds ratio (OR) between 3 and $6[1,4,5]$. In addition to a pure estimate of breast cancer risk, mammographic density (MD) has been shown to indicate the increase of breast cancer risk under hormone replacement therapy (HRT) and to indicate the decrease of breast cancer risk under a chemoprevention with tamoxifen [6,7]. Recent reports showed a link of MD to some genetic variation [8] and to family history of breast cancer as well [9], however mammographic density has not yet been implemented in early detection programs or screening for breast cancer risk prediction not for women without nor for women with a family history of breast cancer [10].

Even though its repeated validation as a breast cancer risk factor in multiple case control and cohort studies, MD has been criticized, because there is no standardized measurement method for MD and most of the methods are subjective, such as the Wolfe's patterns, using four categories [11,12], Boyd's classification, with six categories [13], and subjective assessment of the percentage density by a reader, with values between 0 and $100 \%$ [14]. In addition to these completely subjective methods, several computer-assisted methods have been developed, such as Madena and Cumulus [15-17]. Specifically, these computer programs assess MD as the proportion of the area with dense breast tissue in relation to the whole breast area on a mammogram. These methods have served to date as the gold standard for assessing the percentage mammographic density (PMD). Recently some automated computer measurement methods of breast cancer risk from mammograms have been investigated in some studies [18-20].

Using computer-assisted thresholding methods such as Madena or Cumulus - together with the PMD - other measures of the two-dimensional mammograms are obtained: the total breast area, the nondense area and the dense area. The PMD is calculated by dividing the dense area by the total breast area. It has been hypothesized that the absolute dense area (DA) is an indicator of breast cancer risk as well, because a higher amount of dense breast tissue could directly correlate to a higher probability of one of the cells within the dense area to progress to a malig- nant cell. Furthermore DA has not been as strongly associated with BMI, thus maybe providing some additional information about breast cancer risk, that is more independent from BMI $[21,22]$.

Therefore the aim of our study was to assess the percent mammographic density as a risk factor in a recent German case-control study for breast cancer and to assess whether breast cancer risk can be described more accurately by adding the measurement of the dense area to the prediction model.

\section{Patients and Methods}

$\nabla$

The Bavarian Breast Cancer Cases and Controls (BBCC) studies are case-control studies conducted in northern Bavaria (a state in the southeast of Germany) and are part of the Breast Cancer Association Consortium (BCAC). The BBCC1 study is a case-control and cohort study that aimed at the investigation of genetic and nongenetic biomarkers and their influence on breast cancer risk and prognosis. BBCC1 is part of the studies [23-33]. Likewise the BBCC2 study, on which is reported in this article for the first time, had the same study aims and is part of the BCAC as well. Patients were recruited at the University Breast Center Franconia between 2002 and 2010. All patients were hospital-based and healthy controls were from the same ZIP code area and were invited by newspaper advertisements. They had to be $\geq 18$ years of age, willing to complete a standardized questionnaire on medical history and breast cancer risk factors as well as lifestyle factors and to contribute peripheral blood for germline DNA extraction. All patients were furthermore required to be willing to contribute a flash frozen breast cancer tumor sample for further molecular analysis of the tumor and adjacent healthy breast tissue. A total of 619 patients with invasive breast cancer and 468 healthy individuals were recruited.

Patients with breast cancer were eligible for the mammographic density analysis, if a mammogram from the time of the initial diagnosis was available. All of these cancer cases were incident. Control individuals were eligible if a mammogram was available for them within 6 months before or after completion of the questionnaire. For both, cases and controls, information about HRT use was not taken from the questionnaire, but from the mammography findings, as this information is routinely documented at the time of mammography. The final study population for which mammograms were available consisted of 561 breast cancer patients and 361 healthy control individuals.

\section{Assessment of mammographic percent density}

The computer-based threshold density assessments and breast area measurements were carried out by two readers with explicit training in the method used, and averages of both measurements 
were taken for analysis. Mammographic images were digitized using the CAD PRO Advantage ${ }^{\circledR}$ film digitizer (VIDAR ${ }^{\circledR}$, Herndon, Virginia, USA). This digitizer is capable of registering signals over the full range of film opacity, from clear to fully black, without saturating. It has a very high precision level at 570 dots per inch (DPI), a bit depth of 32 bits gray scale input mapped to a 16-bit (65536) gray scale output, a clinical optical range of 0.05-4.20, and a spatial resolution of $44 \mu \mathrm{m}$. Mammograms were digitized regardless whether they were analogue films or printout of modified digital mammograms. For assessment of the density fraction and the dense area, the reader used the Madena software program, Version X (Eye Physics, LLC, Los Alamitos, California, USA) [17]. The software program assigns a pixel value of 0 to the darkest (black) shade in the image and a value of 255 to the lightest (white) shade, with linear shades of gray being assigned linear intermediate values. The total area of the breast is outlined using a computerized outlining tool, and the total number of pixels within the outline is counted. The density assessment is carried out as follows: the reader outlines a region of interest (ROI), which includes the entire breast but excludes the pectoralis muscle, prominent veins, and fibrous strands. The reader then uses a tinting tool to apply a color to dense pixels with gray levels at or above a threshold of $x \leq 255$. The reader sets the best threshold at which all pixels $\geq \mathrm{x}$ within the ROI can be considered to represent mammographically dense breast areas. The software estimates the total number of pixels and the number of tinted pixels within the ROI (= dense area). The dense area represents the count of the tinted pixels within the ROI. Percentage density, or the fraction (\%) of the breast with densities, is the ratio of the dense area to the total breast area. The mammograms were read in random order by the same two observers, who were unaware of any previous classifications or pathological findings.

\section{Statistical considerations}

Characteristics of breast cancer cases and controls are presented as means and standard deviations or frequencies and percentages. P-values for the appropriate statistical tests indicate the distribution between cases and controls. The Welch t-test was used for continuous characteristics, the $\mathrm{X}^{2}$ test for categorical characteristics and the Wilcoxon rank-sum test for ordinal but not continuous characteristics.

The association between mammographic measures (PMD and DA) and breast cancer risk was analyzed with logistic regression models. PMD and DA were categorized on the basis of quartiles for the purpose of comparison with earlier studies [24,34]. Unad- justed analyses with PMD or DA as single predictor and adjusted analyses with PMD or DA and the well-known risk factors age (continuously), BMI (continuously), parity (ordinally) and menopausal and HRT status (categorically; "premenopausal", "postmenopausal and HRT usage", "postmenopausal and no HRT usage") as predictors were performed. Furthermore, unadjusted and adjusted analyses with models including both mammographic measures as predictors were performed to study the additional predictive value of each mammographic measure, especially whether DA improves the risk prediction in addition to MD. Odds ratios (OR) and their 95\% confidence intervals were estimated for the mammographic measures. The area under the receiver operating characteristic curve (AUC) was calculated for each regression model to compare the predictive strength. The AUC ranges from 0.5 (random prediction) to 1 (perfect prediction). The relative goodness of fit of two nested models was tested with the likelihood ratio test. A significant test result means that the model with more predictors predicts significantly better breast cancer case-control status than the model with fewer predictors.

Additionally, the mammographic measures were analyzed as continuous predictors to show independently of the above chosen categories how breast cancer risk changes when mammographic measures vary. Therefore, logistic regression models with mammographic measures as cubic spline predictors with 2 knots and adjusting predictors as above were used. The models with which the figures were constructed were fitted without patients with MD and DA, respectively, beyond the 10th and 90th percentile to avoid an unreliable curve shape at the outer ranges of the measurements. The model comparisons in the text, however, were based on cubic spline models fitted by the whole data set.

All of the tests were two-sided, and a p-value $<0.05$ was regarded as statistically significant. Calculations were carried out using the $\mathrm{R}$ system for statistical computing (version 2.13.1; R Development Core Team, Vienna, Austria, 2011).

\section{Results}

$\nabla$

A total of 561 cases and 376 controls were analyzed in this study. Patient characteristics are summarized in $\bullet$ Table 1. Healthy control individuals were more likely to have a lower BMI than breast cancer patients $\left(25.5 \mathrm{~kg} / \mathrm{m}^{2}\right.$ vs. $\left.26.9 \mathrm{~kg} / \mathrm{m}^{2}\right)$. Among the healthy controls 21.9\% $(n=70)$ were premenopausal and $78.1 \%(n=249)$

Table 1 Characteristics of cases and control individuals.

\begin{tabular}{|c|c|c|c|c|}
\hline Risk factor & $\begin{array}{l}\text { All }(n=937) \\
\text { mean }(S D) \text { or } n(\%)\end{array}$ & $\begin{array}{l}\text { Cases }(n=561) \\
\text { mean }(S D) \text { or } n(\%)\end{array}$ & $\begin{array}{l}\text { Controls }(n=376) \\
\text { mean }(S D) \text { or } n(\%)\end{array}$ & p-value \\
\hline Age at mammogram (years) & $59.3(11.7)$ & $60.8(12.1)$ & $57.0(10.5)$ & $<0.0001$ \\
\hline BMI & $26.9(5.5)$ & $26.9(5.5)$ & $25.5(4.6)$ & $<0.0001$ \\
\hline Parity & & & & 0.32 \\
\hline$>0$ & $153(16.3 \%)$ & $88(15.9 \%)$ & $65(17.4 \%)$ & \\
\hline$>1$ & $220(23.8 \%)$ & $138(25.0 \%)$ & $82(22.0 \%)$ & \\
\hline$>2$ & $371(40.1 \%)$ & $205(37.1 \%)$ & $166(44.5 \%)$ & \\
\hline > $3+$ & $182(19.7 \%)$ & $122(22.1 \%)$ & $60(16.1 \%)$ & \\
\hline Menopausal and HRT status & & & & $<0.0001$ \\
\hline Premenopausal & $184(21.5 \%)$ & $114(21.2 \%)$ & $70(21.9 \%)$ & \\
\hline - Postmenopausal with HRT use & $296(34.6 \%)$ & $158(29.4 \%)$ & $138(43.3 \%)$ & \\
\hline - Postmenopausal with no HRT use & $376(43.9 \%)$ & $265(49.4 \%)$ & $111(34.8 \%)$ & \\
\hline
\end{tabular}


were peri- or postmenopausal. Among the breast cancer patients $21.2 \%(n=114)$ were premenopausal and 78.8\% $(n=423)$ were peri- or postmenopausal. Within the group of postmenopausal patients $55.4 \%(n=138)$ of the controls were HRT users and $37.4 \%(n=158)$ of the breast cancer patients. There were no differences concerning the parital status or with regards to age ( Table 1). Age was different between the groups as the patient groups were not age-matched but for the study aim, this was taken into consideration by adjusting for it in the multivariate analysis.

As PMD is the proportion of the dense area to the whole breast area, the values of the dense area were highly correlated with the PMD (Spearman's $\rho=0.70$, $\odot$ Fig. 1 ). It seems that for women with a small PMD and a small DA, the correlation is somewhat stronger than for women with a high PMD and a large DA.

Percent mammographic density and dense area were associated with those risk factors that are commonly known to be associated with mammographic density with the expected effect sizes and directions ( Table 2). BMI was stronger correlated with $\operatorname{PMD}(\rho=-0.56)$ than with DA $(\rho=-0.11)$. Likewise Association with age was stronger for PMD $(\rho=-0.45)$ than for DA $(\rho=-0.29)$. The association for parity was of similar strength.

We built several logistic regression models to assess their ability to predict case-control status. The models were then compared in order to answer the primary study aim, whether the parameter DA contributes to a better predictive value of the model as assessed by AUC and compared by the likelihood ratio test.

In the multivariate analysis including commonly known risk factors and mammographic density, quartiles of mammographic density, the predictive value concerning breast cancer risk was confirmed. The first quartile comprised women with mammographic densities from 0 to $21 \%$ and was our reference group for all comparisons ( Table 3). The OR for women with a mammographic density within quartile 2 (PMD from 21-32\%), quartile 3 (PMD from 33-49\%) and quartile 4 (PMD more than 49\%) were 1.64 (95\% CI: 1.06-2.52), 1.57 (95\% CI: 1.00-2.46) and 2.12 (95\% CI: $1.25-3.62)$. The AUC for this model was 0.66 as compared to 0.65 for the model including only commonly known risk factors. The predictive value was significantly better for the first model $(p=0.03$, likelihood ratio test). $\odot$ Fig. 2 shows continuous ORs for PMD estimated by a cubic spline regression model. The log ORcurve agrees with the categorical OR from above. The predictive power of both PMD models coincide (both AUCs were 0.66), i.e., the chosen categories seem to be sensible.

Similar analysis for the dense areas showed the following adjusted OR for the quartiles ( Table 4). Q2: OR=0.92 (95\% CI: 0.60-1.39), Q3: OR=1.10 (95\% CI: 0.72-1.70) and Q4: OR = 0.75 (95\% CI: 0.49-1.15). Overall there seemed to be no correlation between the DA and breast cancer risk. The AUC remained 0.65 regardless of whether DA was included in the prediction model

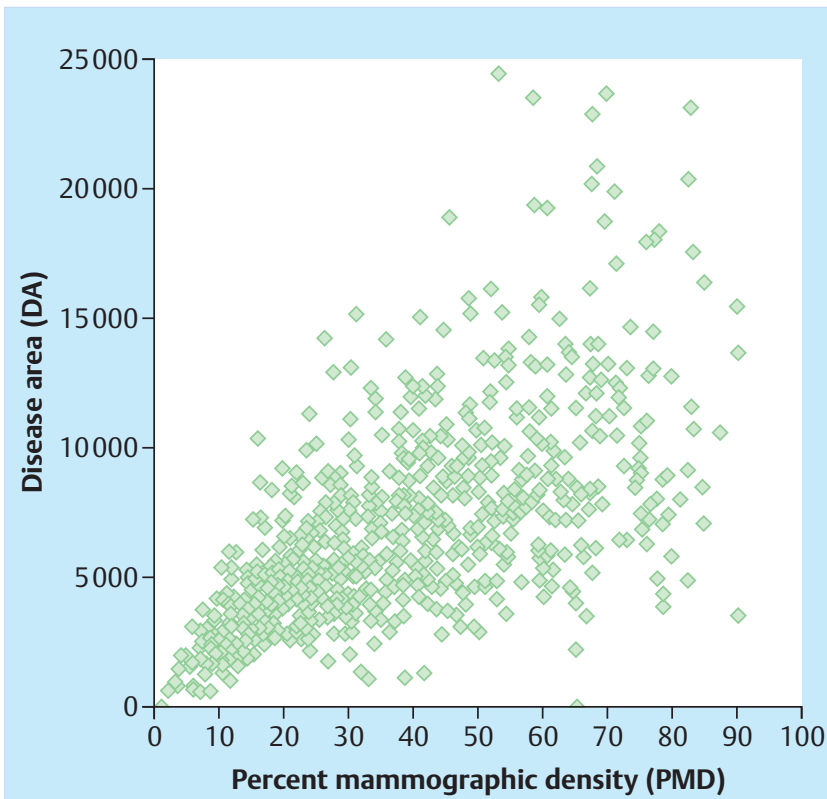

Fig. 1 Association between percent mammographic density in percent (PMD) and the dense area in pixels (DA).

Table 2 Correlation between patient charactistics and mammographic measures. Spearman's correlation coefficient $\rho$ is shown.

\begin{tabular}{|llll|}
\hline Risk factor & $\begin{array}{l}\text { All } \\
(\mathbf{n = 9 3 7 )}\end{array}$ & $\begin{array}{l}\text { Cases } \\
(\mathbf{n = 5 6 1 )}\end{array}$ & $\begin{array}{l}\text { Controls } \\
(\mathbf{n = 3 7 6})\end{array}$ \\
\hline Percent mammographic density & \\
\hline BMl at mammogram & -0.45 & -0.44 & -0.45 \\
\hline Parity & -0.56 & -0.55 & -0.56 \\
\hline Dense area (DA) & -0.12 & -0.12 & -0.13 \\
\hline & 0.70 & 0.68 & 0.70 \\
\hline Age at mammogram & Dense area & & \\
\hline BMI & -0.29 & -0.24 & -0.31 \\
\hline Parity & -0.11 & -0.10 & -0.08 \\
\hline
\end{tabular}

or not. The model comparison with the likelihood ratio test yielded $\mathrm{p}=0.29$. $\triangle$ Fig. 3 shows continuous ORs for DA. As before, the log OR-curve agrees with the categorical OR, and both DA models had the same AUC value.

Including both mammogram measurements, PMD and DA, improved the prediction model further. The AUC for a prediction model including commonly known risk factors, PMD and DA was 0.68. Comparing the models with the likelihood ratio test showed that this model was better than the model that only in-

Table 3 Percent mammographic density (PMD) as a risk factor for breast cancer. Odds ratios (OR) with 95\% confidence intervals in brackets and corresponding pvalues are shown.

\begin{tabular}{|llllr|}
\hline PMD categories (quartiles) & OR unadjusted & p-value & \multicolumn{1}{l|}{$\begin{array}{l}\text { OR adjusted for age, menopausal status } \\
\text { and HRT-usage, BMI, parity } \\
1 \text { (reference) }\end{array}$} \\
\hline Q1 $(<21)$ & 1 (reference) & - & $1.64(1.06,2.52)$ & - \\
\hline Q2 $(21-32)$ & $1.25(0.86,1.82)$ & 0.25 & $1.57(1.00,2.46)$ & 0.03 \\
\hline Q3 (33-49) & $0.93(0.64,1.35)$ & 0.71 & $2.12(1.25,3.62)$ & $<05$ \\
\hline Q4 $(>49)$ & $0.76(0.53,1.10)$ & 0.15 & 0.01 & \\
\hline
\end{tabular}



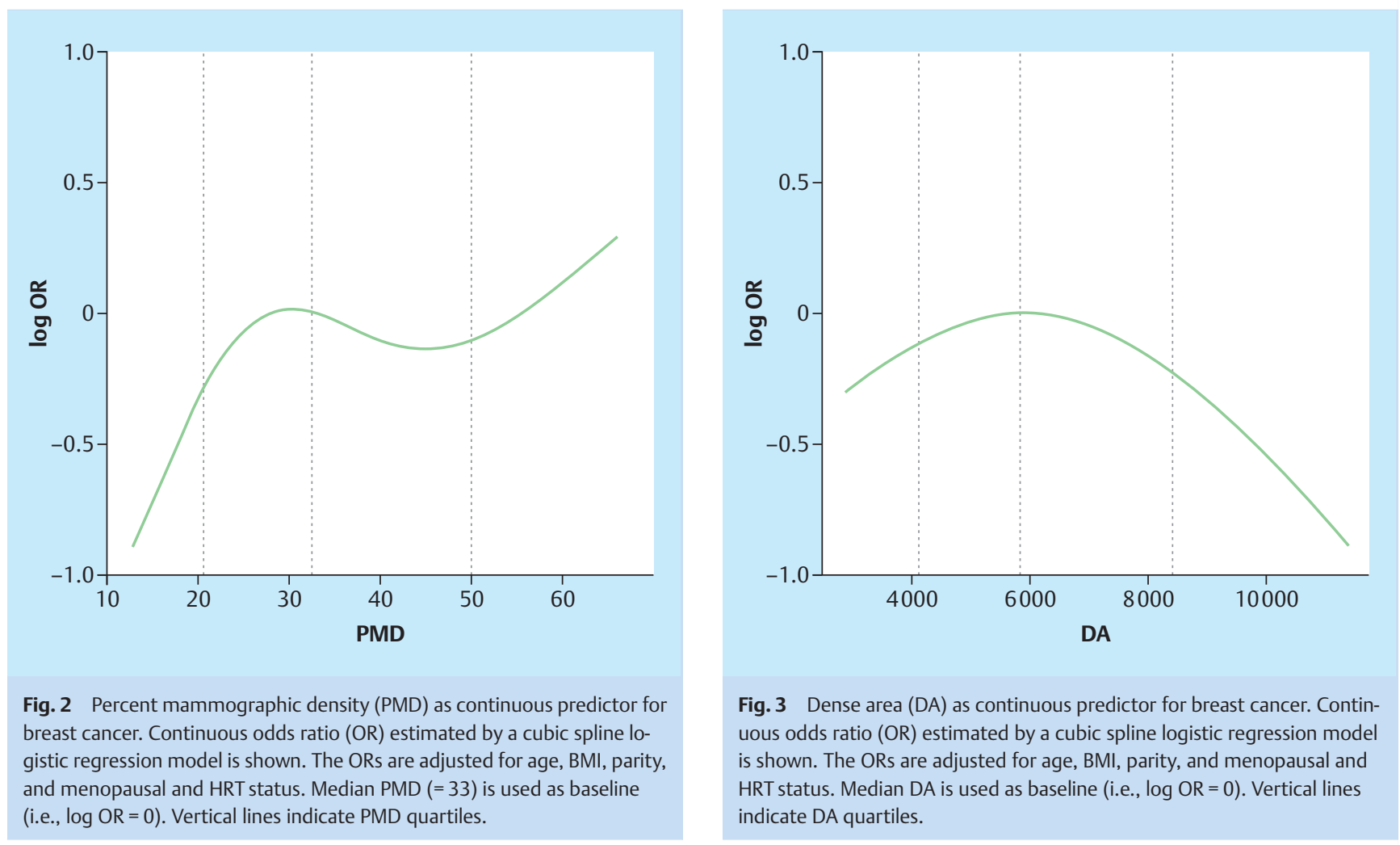

Table 4 Dense area (DA) as a risk factor for breast cancer. Odds ratios with 95\% confidence intervals in brackets and corresponding p-values are shown.

\begin{tabular}{|c|c|c|c|c|}
\hline DA categories (quartiles) & OR unadjusted & p-value & $\begin{array}{l}\text { OR adjusted for age, menopausal status } \\
\text { and HRT-usage, BMI, parity }\end{array}$ & p-value \\
\hline Q1 & 1 (reference) & - & 1 (reference) & - \\
\hline Q2 & $0.80(0.55,1.17)$ & 0.25 & $0.92(0.60,1.39)$ & 0.68 \\
\hline Q3 & $0.88(0.60,1.28)$ & 0.50 & $1.10(0.72,1.70)$ & 0.65 \\
\hline Q4 & $0.56(0.39,0.81)$ & $<0.01$ & $0.75(0.49,1.15)$ & 0.19 \\
\hline
\end{tabular}

cluded risk factors $(\mathrm{p}<0.001)$, better than the model that included risk factors and DA $(\mathrm{p}<0.001)$ and better than the model including risk factors and PMD $(\mathrm{p}<0.01)$. The additional predictive value of DA became apparent by the highly significant ORs for PMD when DA is considered as adjusting variable ( $\bigcirc$ Table 3 ) and by the significant OR for DA when PMD is considered as adjusting variable ( Table 4).

\section{Discussion}

$\nabla$

In this breast cancer case-control study we could confirm mammographic density as a risk factor in a German population. In addition to the biomarker percent mammographic density, the absolute dense area on the mammogram was examined with regard to breast cancer risk prediction. DA alone was not predictive, but the addition of DA to commonly known risk factors and PMD did improve the prediction of breast cancer risk.

To our knowledge this is the second breast cancer case-control study from Germany which has examined mammographic characteristics with regards to breast cancer risk. Previously we reported on a population of patients in another study, which was larger and the individuals were recruited in an earlier time period [24]. With regard to adjusted OR the two studies have very comparable results. Patients with a PMD within the highest quartile have an OR of 2.12 (95\% CI: 1.25-3.62) in the recent study and 2.3 (95\% CI: 1.5-3.6) in the older study [24]. The unadjusted OR are somewhat different ( Table 3). However PMD is highly correlated with several factors that are known to be correlated with breast cancer risk and PMD (e.g. BMI, age, parity, HRT use) [35, 36]. Therefore these differences could be explained by differences between both populations concerning these parameters. Comparing the recent and the older study with other breast cancer risk studies of mammographic density, the risk levels as assessed by our group in Germany seem to be slightly lower than in other published reports [4].

The primary aim of this analysis was to assess in how far absolute DA of a mammogram can or cannot improve the estimation of breast cancer risk. It is known that mammographic dense areas are highly correlated to both, the amount of epithelial breast cells and the amount of extracellular matrix $[37,38]$. Therefore the DA might have a higher correlation to the absolute count of epithelial cells, and it has been hypothesized that the correlation of breast 
cancer risk with mammographic characteristics could be explained stochastically.

An Australian study examined a similar question [39] like our study and found DA to be a better predictor than PMD with regards to breast cancer risk. Estimates of the OR concerning PMD were very similar to our study, however this correlation was not maintained when adding dense area to the prediction model and PMD lost its predictive value [39]. Our findings show that DA helps to improve the overall estimation of breast cancer risk, however when used alone without PMD there was no association with breast cancer risk. As both PMD and DA are assessed together during the measurement of a mammogram both values can easily be used for a prediction model. Therefore we suggest to use both mammographic characteristics and not only one as implied by Stone et al. [39].

Although we could show that the inclusion of DA in a prediction model improves the strength of the prediction of the case control status, different from other studies [34,40-43] we could not show that the dense area without including PMD into the logistic regression model was associated with breast cancer risk. All other parameters (age, menopausal status, HRT use, BMI and parital status) however were correlated with DA in an expected way (O Table 2) [21].

There are some strengths and some weaknesses to this study that should be taken into consideration when interpreting our results. One of the weaknesses could be the limited power due to sample size. Mammographic density and dense area are known to be influenced by a series of confounders that are associated with mammographic density and breast cancer risk as well. In our study some of the subgroups were rather small, and therefore some of the described effects could be due to chance. However when comparing the OR for PMD quartiles after adjustment for these risk factors there seemed to be an effect size that was comparable to our first study [24]. Our cases were hospital-based and the controls were invited by newspaper advertisements. This could be the reason that we found more HRT users in controls than in cases. Other studies by our group could show that awareness of breast cancer risk factors is associated with a higher willingness to take part in breast cancer prevention trials $[44,45]$. Therefore women who are aware of HRT as a risk factor for breast cancer could be more willing to serve as controls for a breast cancer case control study. Strengths of this study are the assessment of mammographic density and the availability of biomaterials. Every mammogram was assessed using a computer-assisted method and each mammogram was assessed by two different readers, who were not aware of the other reader's results. The average of both measurements was taken for analysis. This may reduce measurement inaccuracies. Another strength of this study is that biomaterials of all patients are available and can be used to answer further molecular questions concerning breast cancer risk genes or gene expression within the tumor, however this is not part of the analysis we present here. It is known however that the availability of frozen tumors is associated with slightly larger tumors, as a sample is more difficult to obtain from smaller tumors. This as well could have influenced the characteristics of the patient population.

\section{Conclusion}

\section{$\nabla$}

The use of imaging characteristics of the breast for breast cancer risk estimation is established and used in many case-control and cohort studies. Besides percent mammographic density, there seem to be more characteristics that are either detectable by automated methods [18] or to be found in the third dimension [46]. One parameter that is easy to assess together with percent mammographic density is the dense area. The use of dense area alone should be investigated in further studies, as our results were conflicting with other studies. It seems to be reasonable to include the measurement of dense area into a breast cancer risk prediction model, as it improves the strength of a prediction model.

\section{Conflict of Interest}

$\nabla$

None.

\section{Affiliations}

${ }^{1}$ Department of Gynecology and Obstetrics, University Hospital Erlangen, Erlangen

${ }^{2}$ Institute of Human Genetics, Friedrich-Alexander University ErlangenNuremberg, Erlangen

${ }^{3}$ Institute of Radiology, University Hospital Erlangen, Erlangen

${ }^{4}$ Institute of Pathology, University Hospital Erlangen, Erlangen

\section{References}

1 Fasching PA, Ekici AB, Adamietz B et al. Breast cancer risk - genes, enviroment, and clinical practice. Geburtsh Frauenheilk 2011; 71: 1056-1066, DOI: 10.1055/s-0031-1280437

2 Mavaddat N, Antoniou AC, Easton DF et al. Genetic susceptibility to breast cancer. Mol Oncol 2010; 4: 174-191, DOI: 10.1016/j.molonc. 2010.04.011

3 Spiegelman D, Colditz GA, Hunter D et al. Validation of the Gail et al. model for predicting individual breast cancer risk. J Natl Cancer Inst 1994; 86: 600-607

4 McCormack VA, dos Santos Silva I. Breast density and parenchymal patterns as markers of breast cancer risk: a meta-analysis. Cancer Epidemiol Biomarkers Prev 2006; 15: 1159-1169, DOI: 10.1158/1055-9965. EPI-06-0034

5 Kolberg H-C, Lüftner D, Lux MP et al. Breast cancer 2012 - new aspects. Geburtsh Frauenheilk 2012; 72: 602-615

6 Cuzick J, Dowsett M, Pineda S et al. Prognostic value of a combined estrogen receptor, progesterone receptor, Ki-67, and human epidermal growth factor receptor 2 immunohistochemical score and comparison with the genomic health recurrence score in early breast cancer. J Clin Oncol 2011; 29: 4273-4278, DOI: 10.1200/JCO.2010.31.2835

7 Boyd NF, Melnichouk O, Martin LJ et al. Mammographic density, response to hormones, and breast cancer risk. J Clin Oncol 2011; 29: 2985-2992, DOI: 10.1200/JCO.2010.33.7964

8 Vachon CM, Scott CG, Fasching PA et al. Common breast cancer susceptibility variants in LSP1 and RAD51L1 are associated with mammographic density measures that predict breast cancer risk. Cancer Epidemiol Biomarkers Prev 2012; DOI: 10.1158/1055-9965.EPI-12-0066

9 Martin LJ, Melnichouk O, Guo H et al. Family history, mammographic density, and risk of breast cancer. Cancer Epidemiol Biomarkers Prev 2010; 19: 456-463, DOI: 10.1158/1055-9965.EPI-09-0881

10 Kast K, Distler W, Schmutzler R. Current recommendations for the prevention and treatment of hereditary breast cancer. Geburtsh Frauenheilk 2010; 70: 634-639, DOI: 10.1055/s-0030-1250167

11 Wolfe JN, Saftlas AF, Salane M. Mammographic parenchymal patterns and quantitative evaluation of mammographic densities: a case-control study. AJR Am J Roentgenol 1987; 148: 1087-1092

12 Wolfe JN. Breast patterns as an index of risk for developing breast cancer. AJR Am J Roentgenol 1976; 126: 1130-1137

13 Boyd NF, Byng JW, Jong RA et al. Quantitative classification of mammographic densities and breast cancer risk: results from the Canadian National Breast Screening Study. J Natl Cancer Inst 1995; 87: 670-675 
14 Gao J, Warren R, Warren-Forward H et al. Reproducibility of visual assessment on mammographic density. Breast Cancer Res Treat 2008; 108: 121-127, DOI: 10.1007/s10549-007-9581-0

15 Boyd NF, Martin LJ, Yaffe M et al. Mammographic density. Breast Cancer Res 2009; 11 (Suppl. 3): S4, DOI: 10.1186/bcr2423

16 Byng JW, Boyd NF, Fishell E et al. The quantitative analysis of mammographic densities. Phys Med Biol 1994; 39: 1629-1638

17 Ursin G, Astrahan MA, Salane M et al. The detection of changes in mammographic densities. Cancer Epidemiol Biomarkers Prev 1998; 7: 4347

18 Haeberle L, Wagner F, Fasching PA et al. Characterizing mammographic images using generic texture features. Breast Cancer Res 2012; 14 : R59, DOI: $10.1186 /$ bcr3163

19 Manduca A, Carston MJ, Heine JJ et al. Texture features from mammographic images and risk of breast cancer. Cancer Epidemiol Biomarkers Prev 2009; 18: 837-845, DOI: 10.1158/1055-9965.EPI-08-0631

20 Heine JJ, Cao K, Beam C. Cumulative sum quality control for calibrated breast density measurements. Med Phys 2009; 36: 5380-5390

21 Stone J, Warren RM, Pinney E et al. Determinants of percentage and area measures of mammographic density. Am J Epidemiol 2009; 170: 1571-1578, DOI: 10.1093/aje/kwp313

22 Schulz-Wendtland R, Dilbat G, Bani M et al. Full field digital mammography (FFDM) versus CMOS technology versus tomosynthesis (DBT) which system increases the quality of intraoperative imaging? Geburtsh Frauenheilk 2012; 72: 532-538

23 Fasching PA, Loehberg CR, Strissel PL et al. Single nucleotide polymorphisms of the aromatase gene (CYP19A1), HER2/neu status, and prognosis in breast cancer patients. Breast Cancer Res Treat 2008; 112: 89-98, DOI: 10.1007/s10549-007-9822-2

24 Heusinger K, Loehberg CR, Haeberle L et al. Mammographic density as a risk factor for breast cancer in a German case-control study. Eur J Cancer Prev 2011; 20: 1-8, DOI: 10.1097/CEJ.0b013e328341e2ce

25 Fasching PA, Pharoah PD, Cox A et al. The role of genetic breast cancer susceptibility variants as prognostic factors. Hum Mol Genet 2012; DOI: $10.1093 / \mathrm{hmg} / \mathrm{dds} 159$

26 Lambrechts D, Truong T, Justenhoven C et al. 11q13 is a susceptibility locus for hormone receptor positive breast cancer. Hum Mutat 2012, DOI: 10.1002/humu.22089

27 Schrauder M, Frank S, Strissel PL et al. Single nucleotide polymorphism $\mathrm{D} 1853 \mathrm{~N}$ of the ATM gene may alter the risk for breast cancer. J Cancer Res Clin Oncol 2008; 134: 873-882, DOI: 10.1007/s00432-008-0355-9

28 Azzato EM, Tyrer J, Fasching PA et al. Association between a germline OCA2 polymorphism at chromosome $15 \mathrm{q} 13.1$ and estrogen receptornegative breast cancer survival. J Natl Cancer Inst 2010; 102: 650662, DOI: $10.1093 /$ jnci/djq057

29 Milne RL, Benitez J, Nevanlinna $\mathrm{H}$ et al. Risk of estrogen receptor-positive and -negative breast cancer and single-nucleotide polymorphism 2q35-rs13387042. J Natl Cancer Inst 2009; 101: 1012-1018, DOI: $10.1093 /$ jnci/djp167

30 Yang XR, Chang-Claude J, Goode EL et al. Associations of breast cancer risk factors with tumor subtypes: a pooled analysis from the Breast Cancer Association Consortium studies. J Natl Cancer Inst 2011; 103: 250-263, DOI: 10.1093/jnci/djq526
31 Antoniou AC, Wang X, Fredericksen ZS et al. A locus on 19p13 modifies risk of breast cancer in BRCA1 mutation carriers and is associated with hormone receptor-negative breast cancer in the general population. Nat Genet 2010; 42: 885-892, DOI: 10.1038/ng.669

32 Ghoussaini M, Fletcher O, Michailidou K et al. Genome-wide association analysis identifies three new breast cancer susceptibility loci. Nat Genet 2012; 44: 312-318, DOI: 10.1038/ng.1049

33 Haiman CA, Chen GK, Vachon CM et al. A common variant at the TERTCLPTM1 L locus is associated with estrogen receptor-negative breast cancer. Nat Genet 2011; 43: 1210-1214, DOI: 10.1038/ng.985

34 Vachon CM, Brandt KR, Ghosh K et al. Mammographic breast density as a general marker of breast cancer risk. Cancer Epidemiol Biomarkers Prev 2007; 16: 43-49, DOI: 10.1158/1055-9965.EPI-06-0738

35 Boyd NF, Martin LJ, Sun L et al. Body size, mammographic density, and breast cancer risk. Cancer Epidemiol Biomarkers Prev 2006; 15: 2086 2092, DOI: 10.1158/1055-9965.EPI-06-0345

36 Loehberg CR, Heusinger K, Jud SM et al. Assessment of mammographic density before and after first full-term pregnancy. Eur J Cancer Prev 2010; 19: 405-412, DOI: 10.1097/CEJ.0b013e32833ca1f4

37 Boyd NF, Martin LJ, Yaffe MJ et al. Mammographic density and breast cancer risk: current understanding and future prospects. Breast Cancer Res 2011; 13: 223, DOI: 10.1186/bcr2942

38 Schulz-Wendtland R, Bani M, Lux MP et al. Pilot study on the detection of simulated lesions using a 2D and 3D digital full-field mammography system with a newly developed high resolution detector based on two shifts of a-Se. Geburtsh Frauenheilk 2012; 72: 408-411

39 Stone J, Ding J, Warren RM et al. Using mammographic density to predict breast cancer risk: dense area or percentage dense area. Breast Cancer Res 2010; 12: R97, DOI: 10.1186/bcr2778

40 Maskarinec G, Meng L. A case-control study of mammographic densities in Hawaii. Breast Cancer Res Treat 2000; 63: 153-161

41 Ursin $\mathrm{G}, \mathrm{Ma} \mathrm{H}, \mathrm{Wu} \mathrm{AH}$ et al. Mammographic density and breast cancer in three ethnic groups. Cancer Epidemiol Biomarkers Prev 2003; 12: 332-338

42 Nagata C, Matsubara T, Fujita $\mathrm{H}$ et al. Mammographic density and the risk of breast cancer in Japanese women. Br J Cancer 2005; 92: 21022106, DOI: $10.1038 /$ sj.bjc.6602643

43 Torres-Mejia G, De Stavola B, Allen DS et al. Mammographic features and subsequent risk of breast cancer: a comparison of qualitative and quantitative evaluations in the Guernsey prospective studies. Cancer Epidemiol Biomarkers Prev 2005; 14: 1052-1059, DOI: 10.1158/ 1055-9965.EPI-04-0717

44 Fasching PA, von Minckwitz G, Fischer T et al. The impact of breast cancer awareness and socioeconomic status on willingness to receive breast cancer prevention drugs. Breast Cancer Res Treat 2007; 101: 95-104, DOI: 10.1007/s10549-006-9272-2

45 Loehberg CR, Jud SM, Haeberle L et al. Breast cancer risk assessment in a mammography screening program and participation in the IBIS-II chemoprevention trial. Breast Cancer Res Treatment 2010; 121: 101-110, DOI: $10.1007 / \mathrm{s} 10549-010-0845-8$

46 Boyd N, Martin L, Chavez S et al. Breast-tissue composition and other risk factors for breast cancer in young women: a cross-sectional study. Lancet Oncol 2009; 10: 569-580, DOI: 10.1016/S1470-2045(09) 70078-6 